\section{ACRL}

Cuidelines

\title{
Guidelines for university undergraduate libraries: A draft
}

\section{Attend the hearings in Chicago on Monday, June 26, 4:30-5:30 p.m.}

$\boldsymbol{U}$ ndergraduate libraries have been established with the primary mission of meet ing the library and information needs of undergraduate students enrolled in the large university environment. These guidelines identify the principal factors influencing the development and maintenance of undergraduate library services and collections. In addition, a review of these factors as they relate to local circumstances should assist in evaluating the need for a separate undergraduate library and enable assessment of whether an unclergraduate library should be established or continued.

\section{Campus environment}

Library systems at large universities generally consist of a main university library plus several branch or special libraries. The large campus environment often defines the quality of the library in terms of the strengths and size of the research collection. Concentration of the main and branch libraries is frequently on the needs of specific fields or departments of study at a research level. These factors create an intimidating environment for many undergraduate students. The needs of academic library users fall on a spectrum with use of introductory research materials and instruction in the research process at one end, and primasy source materials and bibliographic services at the other end. Undergraduate libraries concentrate on the former.

Primary clientele: Undergraduate students enter the university with varying levels of experience and information skills and share many of the following characteristics:
1. They are beginning to acquire the research skills needed to exploit the research library's potential.

2. They need a user-friendly environment where assistance is offered and questions are encouraged.

3. They need to be introduced through library instruction, either one-on-one or through coursework, to the academic nature of the ser vices and resources available in university libraries.

4. They are most often enrolled in courses where assignments have short deacllines requiring just-in-time library services. These courses often have large enrollments.

Other clientele: The undergraduate library may also serve the instructional and informational needs of university staff and faculty, as well as members of the civic community.

\section{Communications}

In undergraduate libraries, the goal of all communications is assuring the effective provision of library services to all clientele. Undergraduate libraries focus on two types of communication: a) communication which informs or gives instruction about library services and use, i.e., public awareness and library instruction, and b) communication which provides information directly, i.e., reference services.

It is the responsibility of personnel in undergraduate libraries to communicate effectively with students, faculty, colleagues, and library and university administrators about library services and collections available to and/or needed by undergraduate students. Additionally, personnel in undergraduate libraries promote use of library services through advocacy and ongoing interaction with university groups who work with undergraduate students and their curricula. 


\section{Programs}

To facilitate academic success, undergraduate libraries must provide access to a broad range of information resources. This access includes reference and referral services, orientation, and bibliographic instruction. Teaching students the critical thinking skills necessary for using a library is a basic service provided by the personnel of undergraduate libraries. The teaching programs of unciergraduate libraries are varied and innovative. They include teaching by personal contact and through the preparation and use of instructional materials in various formats. They include formal group instruction and informal, unstructured contacts with students. Reference, bibliographic instruction, and orientation activities are appropriate for all levels and types of library users. Undergraduate libraries provide a laboratory for clientele to acquire information literacy skills: identification of needed information, effective and ethical use of intellectual and physical resources, and knowledge of when to ask for help and the confidence to do so. Undergraduate libraries serve as a gateway to all future library in quiry, preparing students not merely for graduate work and research but also teaching them to use information sources as citizens, as consumers, as professionals, and for recreational purposes.

Reference and referral service for undergracluates often involves not only answering specific questions, but also personalized instruction in the methods of identifying and retrieving library materials. Supplemental to this personal contact is the provision of clatabase interfaces, bibliographies, and other aids designed to introduce undergraduates to the materials available in the library and to guide them in finding the materials. The reference service provided by undergraduate librarians is a referral service to the wide variety of resources in the library system. Referrals maty also assist undergraduates in becoming aware of branch or specialized libraries, and campus supportive services including academic, financial, writing, and counseling services.

Orientation activities acquaint undergraduates with the facilities and services of the library system. They include activities such as the distri- bution of maps and informational materials which describe the library system and the resources and services of the individual libraries within it, staff-conducted tours for groups, and self-guided tours. Orientation may also include public relations activities to help students become aware of the information resources available within the university community or on any information network.

Bibliographic instruction programs should improve the ability of students to make effective use of the library collections, services, and staff. Instruction may be offered as part of coursework in an academic subject or interdisciplinary program, in a separate course on library skills, in workshops and term-paper clinics, and through point-of-use aids in the library.

\section{Resources}

Effective undergraduate libraries require adequate resources to accomplish their missions. Implicit in the creation of an undergraduate library is a commitment to funding its development, ongoing services, and growth while maintaining library services for the entire academic community. Standards of service in undergraduate libraries should be comparable with other library services offered at the university even if access, personnel, level of collecting, and programs differ significantly.

Personnel: The personnel of undergraduate libraries have the knowledge and abilities to insure effective management and use of the services and collections. In general, undergradu-

\section{Revision of the mission of a university undergraduate library: Model statement}

Work began in 1993 by the ACRL Undergraduate Librarians Discussion Group to update the 1987 Model Mission Statement of a University Undergraduate Library and to change it to guidelines. The revisions were discussed and amended in each of three meetings of the Discussion Group at ALA Midwinter, Denver, 1993; New Orleans, 1993; and Los Angeles, 1994. The resulting draft was submitted to the University Libraries Section (ULS) so that a committee to review the draft could be appointed. The members of the ULS Ad Hoc Committee to Review Draft Guidelines for University Undergraduate Libraries are: Barton Lessin, Wayne State University; Donna Senzig, University of Wisconsin-Madison; Louise Sherby, University of Missouri, Kansas City; and Paula Walker, chair, University of Washington. A hearing will be held at the 1995 ALA Annual Conference in Chicago on Monday, June 26, 4:30-5:30 p.m. For those who cannot attend the hearing, comments may be sent to any committee member, but in particular to the chair: Paula Walker, Odegaard Undergraduate Library, DF-10, University of Washington, Seattle, WA 98195; (206) 543-1947; fax: (206) 685-8485; e-mail: pwalker@u.washington.edu. 
ate libraries require librarians as well as support and part-time staff, depending on the size of the undergraduate population at the institution. The ability to interact on a one-to-one basis with a diverse clientele in a friendly and instructive manner is essential.

Personnel in undergraduate libraries require diversified backgrounds in order to meet the teaching and learning needs of users. Abilities needed include: teaching and knowledge of instructional methods and learning styles; excellent communication skills; and understanding and expertise in information seeking skills. Personnel require flexibility and should be encouraged to take risks and develop innovative programs.

Undergraduate librarians should participate in appropriate professional organizations to assure awareness of special issues affecting undergraduate library services.

Collections: Undergraduate libraries acquire and provide ready access to information resources to meet the needs of their primary clientele with focus on the institution's curriculum. The value of collections in undergraduate libraries is measured by their usability as well as quality and size. Collection and access policies should be written and readily available.

Collection policies for undergraduate libraries consider the following:

1) Because many undergraduate courses require large numbers of students to use the same library materials, direct curriculum support will be provided through reserve collections and through purchase of multiple copies of items with high demand.

2) Undergraduate libraries provide effective access to information resources through reference sources in a variety of formats. Reference collections in undergraduate libraries should concentrate on the more standard and interdisciplinary indexes and sources. Periodical collections should emphasize the titles covered by these indexes.

3) Subject coverage of collections in undergraduate libraries encompasses a broad range of disciplines to meet the information needed for papers, speeches, and projects required in the wide variety of courses taken by undergraduates. More specialized and advanced needs will be met by specific referral to other library sources on campus.

4) The library experience of undergraduates should encourage them to seek information of personal interest. Collection policies should include access to information on current events, cultural interests, career information, and recreational reading, among others, to encourage exploration of information resources as a part of everyday life. Because of the special nature of undergraduate libraries, collection policies should include withdrawal practices. Collections should be dynamic and responsive to the needs of a changing curriculum and clientele.

Effective Learning Environment: Undergraduate libraries have facilities that promote effective and interactive access and use of information resources for all users. Safe, comfortable, well-lighted, clean space with adequate and appropriate seating should be provided to insure effective use of the library's resources, including electronic formats. In physical planning for facilities, undergraduate libraries provide for small group and instructional use. Additionally, undergraduate libraries consider study space needs in allocation of seating and space, with attention to reserve collections and the residential environment of the institution. Undergraduate libraries establish hours of access, circulation policies, and other rules to meet the needs of their primary clientele.

\section{Evaluation}

Performance Measures: Institutions establishing or maintaining an undergraduate library or providing undergraduate library services should apply the basic principles described in "Standards for University Libraries: Evaluation of Performance" (CERL News, September 1989, pp. 679-91). Because of the unique role of undergraduate libraries, the criteria for performance review and method of evaluation may be influenced by the overall library system's specific mission. Criteria for evaluating undergraduate libraries include:

1) Services. The usefulness of an undergraduate library is determined by the effectiveness and quality of the services provided in support of the undergraduate programs of the institution.

a. Do the services offered meet the information needs of the undergraduate students, and the faculty and staff who work with them?

b. Are user studies, statistics, and other measures of quantity and quality collected and utilized effectively?

c. Are library instructional programs available and funded adequately for the support of coursework?

d. Are staff adequately trained and compen- 


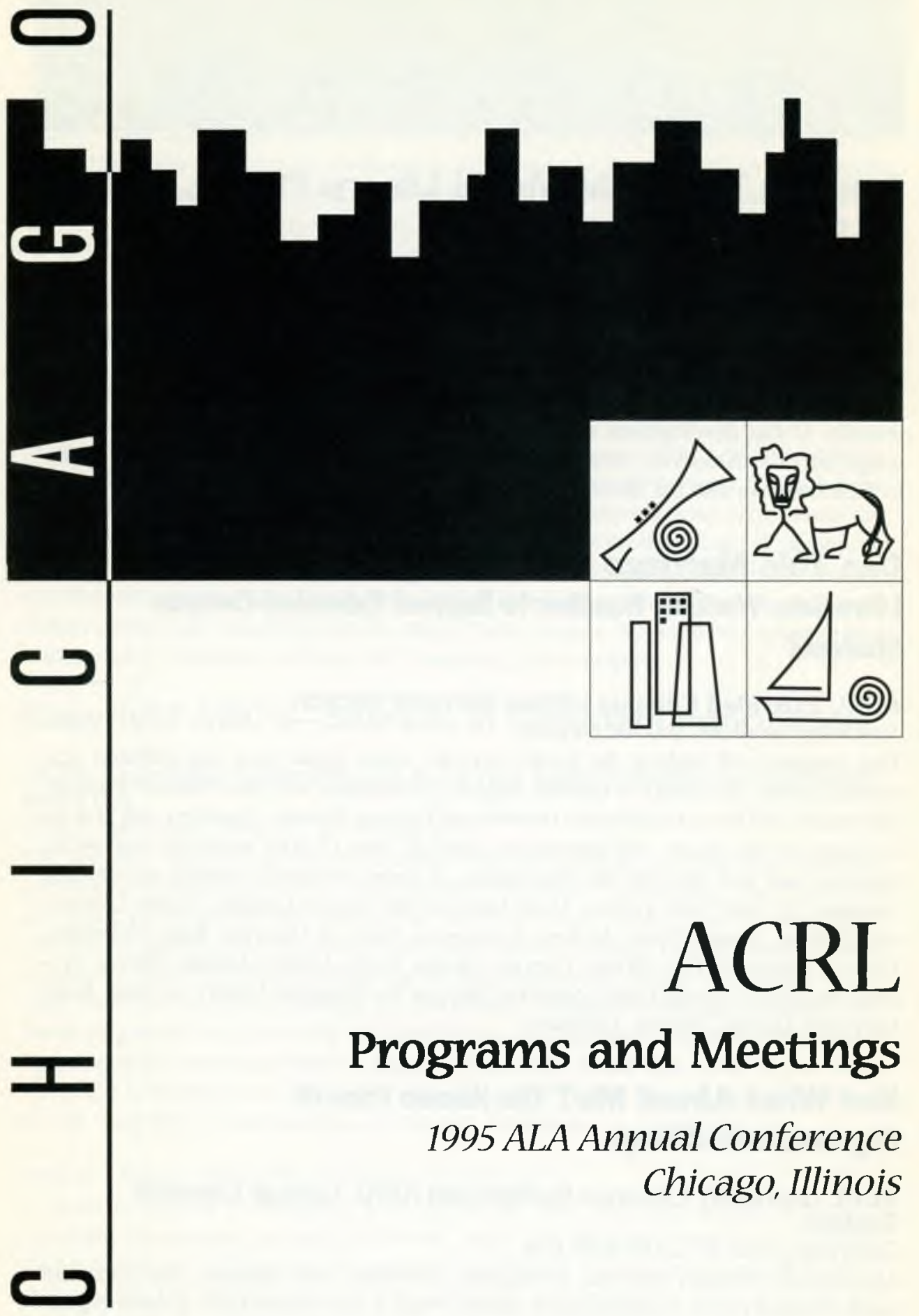

Association of College \& Research Libraries 


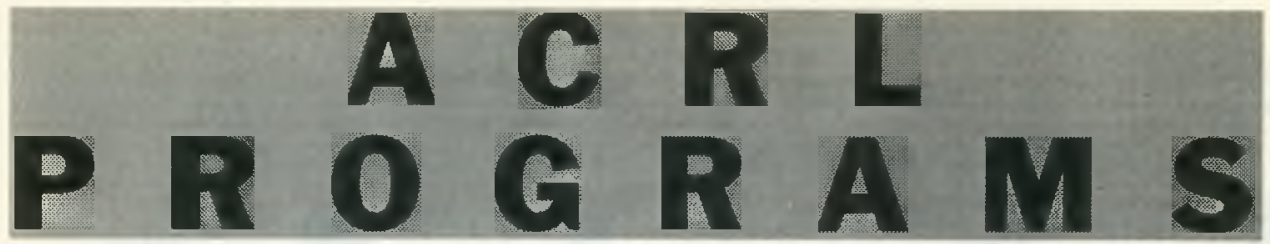

\section{Stepping Toward the Virtual Library: Planning, Practice, and Dreams}

\section{ACRL Community and Junior College Libraries Section Saturday, June 24, 9:30 a.m.-12:30 p.m.}

Experiences of librarians involved at three different stages in the move toward the electronic library will be presented. Speakers will cover the political, practical, and technological issues involved in making these changes at their institutions. Topics include: 1) the development of an integrated technology learning center, 2) a full image periodicals delivery project within a multi-campus setting, and 3) virtual reality in the classroom and the library.

\section{Can This Marriage Be Saved? Academic and Public Librarians Working Together to Support Extended-Campus Students}

\section{ACRL Extended Campus Library Services Section Saturday, June 24, 2:00-4:00 p.m.}

This program will address the issues involved when public and non-affiliated academic libraries are asked to provide support for students who are distance leamers. Discussion will focus on alliances between and among libraries. Speakers will give an overview of the issues, will discuss the point of view of both academic and public libraries, and will describe the negotiation of some successful existing agreements. Speakers: Dr. Julie Beth Todaro, Head Librarian-Rio Grande Campus, Austin Community College, Austin, Texas; Andrew Scrimgeour, Dean of Libraries, Regis University, Denver, Colorado; Tom Moran, Director, Moline Public Library, Moline, Illinois. Program Moderator: Susan Potter, Assistant Director for Extended Library Services, Regis University Library, Denver, Colorado.

\section{But What About Me? The Human Face of Organizational Change}

\section{ACRL University Libraries Section and ACRL College Libraries Section \\ Saturday, June 24, 2:00-4:00 p.m.}

As academic libraries reinvent, re-engineer, downsize, and rightsize, the impact of these changes on their employees is critical. What is the buman face of these organizational changes? How have these changes affected the career paths of individual 


\section{s \\ librarians? In a downsizing environment, how can the library fulfill its institutional commitment to diversity? What are the implications for a unionized workforce? Speak- ers: Rebecca R. Martin, Director of Library and Media Services, The University of Ver- mont; Rita Scherrei, Associate University Librarian, Personnel and Administrative Ser- vices, University of California, Los Angeles; Kriza Jennings, Program Officer for Diversity and Minority Recruitment, Association of Research Libraries; and Hannelore B. Rader, Director, University Library, Cleveland State University. \\ Diverse Images of Chicago Dance: From Cooperative Preservation to Cutting Edge}

\section{ACRL ARTS Section \\ Saturday, June 24, 2:00-4:00 p.m.}

How is dance documented and preserved in the Chicago area? How are dance companies and libraries cooperating to ensure that dance in Chicago leaves a lasting legacy? Three projects are answering these questions in three different ways. This panel discussion/demonstration will feature speakers who are involved in dance documentary projects. Speakers: Diana Haskell, curator, Chicago Dance Archive, Newberry Library; Gail Kalver, executive director, Hubbard Street Dance Co.; Effie Mihopoulus, freelance writer, editor, oral historian; Denise Miller Clark, curator, Museum of Contemporary Photography, Columbia College; Bill Fretterking, photographer.

\section{Copyright ABC's-Sources of Copyright Information}

\section{ACRL Copyright Committee, ALA Ad Hoc Subcommittee on Copyright, and LITA}

Part I: Saturday, June 24, 2:00-4:00 p.m.

Fair use and equitable access of information on the Internet and the future National Information Infrastructure are of vital interest to the library community. "Fair Use in the Electronic Environment" will examine fair use from several perspectives. Speakers: Mary Beth Peters, Register of Copyright of the United States Copyright Office; Kenneth Crews of Indiana University-Purdue University in Indianapolis and author of the book Copyright, Fair Use, and the Challenge for Universities; Willajeanne McLean, Assistant Professor of Law at the University of Connecticut; and Joseph J. Esposito, President of Encyclopaedia Britannica North America. Moderators: Sarah Cox, chair of the ACRL Copyright Committee and Edward J. Valauskas, Chair of the ALA Ad Hoc Subcommittee on Copyright, a subcommittee of the ALA Committee on Legislation.

\section{Part II: Sunday, June 25, 9:30 a.m.-12:30 p.m.}

A panel of experts will identify and discuss the best and most current sources of copyright information, including academic, legal, and electronic resources. This is an essential program for librarians charged with developing or formulating copyright policy, and valuable for anyone with everyday copyright responsibilities. Bibliographies will be distributed. A question-and-answer session will follow the presentations. 


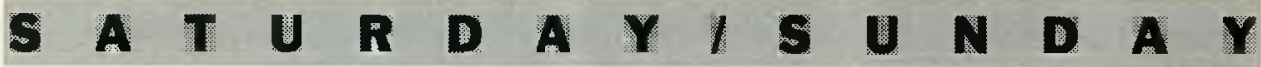

Part III: Monday, June 26, 9:30 a.m.-12:30 p.m.

Explores the issues and examines methods of tracking copyright for nondedicated delivery of electronic full-text directly to the end user. Speakers include Laura Gasaway, Director of the Law Library and Professor of Law, University of North Carolina, Chapel Hill; Don Bosseau, University Librarian, San Diego State University; John Kolman, VicePresident Development, Ameritech Library Services Academic Division; and Randall Marcinko, Vice-President and General Manager, EBSCO Document Services. Moderator: Sandra Hurd, Director of Library Automation, EBSCO Subscription Services.

\section{The United Nations at 50: Information Services, Policies, and Documentation}

\section{ACRL Law and Political Science Section, IRRT, GODORT Saturday, June 24, 2:00-4:00 p.m.}

The availability and dissemination of United Nations information through the first fifty years of the organization and beyond; the United Nations Library and its services; and the possible impact current UN restructuring proposals may have on information policies. Speakers include Rima Bordcosh, Officer in Charge, User Services Section, United Nations Library; Mickie A. Voges, Director, Legal Information Center and Associate Professor of Law, Library of International Relations, Chicago-Kent College of Law; Peter Hajnal, Government Publications Specialist, University of Toronto Library; and Richard Amdur, Information Officer, Department of Public Information, United Nations.

\section{Publishing the Social Text: Issues in Sociology and Anthropology Publication and Reviewing}

\section{ACRL Anthropology and Sociology Section}

Sunday, June 25, 9:30 a.m.-12:30 p.m.

Prominent authors and publishers discuss issues and processes related to anthropology and sociology publishing. Who gets published? How are manuscripts solicited by publishers? What topics are hot? What are current market conditions and how are these influencing scholarly publishing? What is the review process for article and book manuscripts submitted for publication? Speakers include sociologist Edward O. Laumann, University of Chicago; anthropologist George E. Marcus, Rice University; Judith McCulloh, University of Illinois Press; and Martha Peacock, Lynne Rienner Publishers.

\section{Toward the Digital Library: Academic Library Futures}

\section{Association of College \& Research Libraries \\ Sunday, June 25, 9:30-11:00 a.m.}

Although there have been digital library projects developing over the past several years, the announcement of the digital library initiative grants by NSF, ARPA, and NASA in September 1994 formally launched a concerted effort to define those elements 
that will characterize the digital library of the future. The program will provide an understanding of what needs to be done in order to bring the concept of the digital library into reality from the perspective of two NSF digital library initiative grant recipients and a representative from the Library of Congress.

\section{Run Ragged by Riches! Technology and Changing Communications for the Library}

\section{ACRL College Libraries Section and the ACRL University Libraries Section}

Sunday, June 25, 9:30 a.m.-12:30 p.m.

Most librarians working in an information-rich environment are being run ragged by techno-stress and techno-angst. How do we effectively communicate with one another? How do librarians communicate with 'techies'? The speakers will provide some prescriptions for dealing with competition, communication, and changing roles.

\section{The Humanist and the Librarian: Creating a Collaborative Partnership}

\section{ACRL English and American Literature Section}

Sunday, June 25, 9:30 a.m.-12:30 p.m.

The humanist scholar traditionally has worked alone with a minimum of consultation. The advent of new technologies has increased the information available to these scholars, and librarians are eager to learn ways to teach/reach humanists. This program will present ways to stimulate fruitful interaction between the humanist and the humanities librarian. Stephen Wiberley Jr., University of Illinois at Chicago, will discuss types of humanistic scholarship; J. Paul Hunter, University of Chicago, will address the new directions in faculty research; and Marcia Pankake, University of Minnesota, will talk about librarians and teachers as colleagues.

\section{The Age of Anxiety: Balancing Scholarly Needs for Primary Research Materials and Electronic Information}

\section{ACRL Rare Books and Manuscripts Section}

Sunday, June 25, 2:00-4:00 p.m.

This session addresses the need for librarians to make preservation and acquisition decisions to balance the competitive demands to acquire primary source material or invest in information technology. Once a practicing scholar and now a research repository administrator, Douglas Greenberg, President and Director, Chicago Historical Society, will consider scholars' needs for non-traditional primary research materials. While not negating the scholarly need for access to electronic information, Alice Schreyer, Curator of Special Collections, University of Chicago, will make the case for the continuing acquisition of traditional primary research materials. 


\section{The Great Media Convergence: Evolving Relationships Between Campus Media and Information Systems and Services}

\section{ACRL Media Resources Committee \\ Sunday, June 25, 2:00-4:00 p.m.}

There are dramatic changes afoot on college and university campuses as media centers, libraries, and academic computing facilities begin to converge around common tools, resources, and services. This technological convergence, together with changes in the nature of teaching and research, is, in many instances, forcing a wholesale reassessment of the administrative relationships between information and media service units. This program will investigate some of the evolving organizational models for these units on campus, as well as some of the challenges and issues involved in developing and adopting these new models.

\section{Librarians Riding the Bear: Keeping Pace with Russian Publishing}

\section{ACRL Slavic and East European Section}

Sunday, June 25, 2:00-4:00 p.m.

The program will provide the audience with several viewpoints on the challenges of coping with the current state of flux in Russian publishing. The speakers include: June Pachuta Farris, Bibliographer for Slavic and East European Studies, University of Chicago; John Bushnell, co-head of Russian Press Service, Inc.; Yelena Mushtyats, Head of the Foreign Collection of Far Eastern State Technical University in Vladivostok; and Ared Misirliyan, Slavic and East European Cataloger, McGill University.

\section{Measuring Up! Improving Instruction Through Evaluation}

\section{ACRL Bibliographic Instruction Section, ACRL Research Committee, and ALA Library Instruction Round Table}

Sunday, June 25, 2:00-5:30 p.m.

Whether in response to external mandates or the desire to improve user services, interest in the evaluation of library instruction is growing. At this year's ACRL BIS Conference Program, Dr. Georgine Loacker of Alverno College-a leading advocate of educational assessment-will give the keynote address, to be followed by a series of breakout sessions covering such topics as survey development, outcomes assessment, computer-assisted instruction, and instructor evaluation. Each session will provide an opportunity to interact with the speakers. 


\section{Preserving the Record of Science and Technology: A Call to Action}

\section{ACRL Science and Technology Section, ALCTS Preservation and Reformatting Section, and ALCTS Collection Development and Management Section}

Monday, June 26, 8:00-11:00 a.m.

Presentations include "What Is the Record of Science and Technology?" by Helen Samuels, Institute Archivist, Massachusetts Institute of Technology; "The Role of Discipline History Centers" by Joan Warnow-Bluett, Associate Director, Center for History of Physics, American Institute of Physics; "Building Alliances for Disciplinary Preservation" by Samuel Demas, Head, Collection Development and Preservation, Cornell University. Poster sessions on current sci-tech preservation efforts will follow the presentation.

\section{New Feminist Research in Library and Information Science: Implications for Librarianship}

\section{ACRL Women's Studies Section}

Monday, June 26, 9-00-11:00 a.m.

This program brings together library school faculty, including Roma Harris, and practicing librarians to discuss issues of feminist research in the field of library and information science. Faculty will present research on gender and information technology; bibliographic control; and subject headings and classification systems. Respondents will include a library school student, a women's studies librarian, and a children's librarian. Discussion will center around implications of this research for the future of librarianship and how practicing librarians can benefit from this research.

\section{Africa at the Field Museum: Perspectives on the New Permanent Africa Exhibit}

\section{ACRL Asian, African, and Middle Eastern Section, ACRL Afro- American Librarians Section, ACRL Anthropology and Sociology Section, ACRL International Relations Committee, and ALCTS Committee on Cataloging Asian and African Materials Monday, June 26, 9:30 a.m.-12:30 p.m.}

In November 1993, the Field Museum of Natural History in Chicago opened its new permanent Africa exhibit. The opening was preceded by several years of planning which included community involvement. Dr. Deborah L. Mack, Senior Developer of the exhibit, will discuss the new exhibit, its planning, its installation, and the response to it. This will be followed by an opportunity to view the exhibit. All attending this 
program should enter at the west door to the museum. The meeting will be held in Lecture Hall 1. Your conference registration badge is your museum admission. A brief AAMES business meeting will also be held. Attendance is limited to the first 150 to arrive at the museum.

\section{European Connections: Electronic Resources for Western Europe}

\section{ACRL Western European Specialists Section \\ Monday, June 26, 9:30-11:00 a.m.}

In recent years, the number of electronic resources of interest to Western European specialists has increased to a remarkable degree, varying in levels of technological sophistication, from OPACs to specialized listservs, to full-text and image databases. The dissemination of information about these sources, of their content and the means of accessing them, and the politics of electronic publishing, are the focus of this year's program. Prof. James Marchand, University of Illinois at Champaign-Urbana, will speak on network access to Western European archives and reference-type files, including Project Runeberg and the Eurodicautom. Mark Olsen, University of Chicago, is assistant director to the ARTFL Project, a research and service undertaking which provides access to the Treasury of the French language database. Olsen will present an overview of future developments at ARTFL and demonstrate a sample of text/image databases, as exemplified by the Renaissance Dante database and a collection of French revolutionary pamphlets. James Campbell, University of Virginia, will address the political factors impacting electronic publishing. Julie Still, Trenton State College, and current editor of the WESS Newsletter column on electronic resources, will comment on these presentations.

\section{Distance Education in the 21st Century: Removing Campus Walls}

\section{ACRL Education and Behavioral Sciences Services Section} Monday, June 26, 9:30 a.m.-12:30 p.m.

Presenters will discuss their vision of distance education in the 21st century and the implications for library services, as well as evaluate the current state of document delivery and electronic services to distance learners. Speakers: Steven F. Schomburg, University of Illinois and Sharon Edge, University of Louisville.

\section{The Life of the Mind in the 21st Century}

\section{ACRLLITA President's Program}

\section{Monday, June 26, 2:00-4:30 p.m.}

The program will present three eminent scholars and information technologists to reflect on the impact that computing and communications technology is having on the 
work of scholars and teachers. They will focus on changes in the working lives of academics and on what these changes portend for the nature of knowledge, for research and teaching, and for the structure of the academy. The program will paint a picture of the environment that academic librarians and library technologists will confront as they enter the 21st century. Speakers: Michael Joyce, Department of English, Vassar College; Greg Farrington, Dean of the School of Engineering, University of Pennsylvania; Jennifer James, author, writer, and scholar. Moderator: Marshall Keys, Executive Director, NELINET

\section{S P E C I A L E V E N T S}

Lyman Shepard as Frank Loyd Wright: A Dramatic Presentation ACRL Community and Junior Colleges Libraries Section

Friday, June 23, 6:30-9:30 p.m.

Dinner/Program. Following dinner, Shepard uses slides and his own interpretation of Wright to portray the architect throughout his long career. Cost $\$ 35$ for CJCLS members, $\$ 45$ for nonmembers. Reservation deadline, June 2 . For information, contact Judi Mayzel, Oakton Community College, (708) 635-1644 or judim@acs.oakton.edu

\section{LPSS 20th Anniversary Breakfast} ACRL Law and Polttical Sctences Section Saturday, June 24, 8:30-9:30 a.m.

Complementary breakfast for the LPSS membership sponsored by Congressional Quarterly, Inc. Featured speaker: Neil Skene, CQ Editor and Publisher. Seating by advance reservation. Contact Ron Heckart, LPSS chair at (510) 6436445 (voice), (510) 642-3020 (fax), or rheckart@library.berkeley.edu

\section{Learning Resources Center College of DuPage Tour}

ACRL Community and Junior College Libraries Section

Monday, June 26, 7:30-11:30 a.m.

Buses will take participants to College of DuPage for a tour of the Learning Resources Center. The LRC utilizes six modules of Innovative Interface's computer systems, including a graphical interface. Other computer systems will also be featured including Ariel. The tour will include the brand new addition of the LRC. (Tour sponsored by Innovative Interfaces, Minolta Document Imaging, Inc., and University Copy Services, Inc.)

Buses leave the south side of the Hilton at 7:30 a.m. and return to McCormick Place with a stop at the Hilton. Cost is $\$ 10$, which includes a continental breakfast. Advance registration deadline: June 2. For information, contact Bob Veihman at College of DuPage, (708) 858-2800, ext. 2659.

\section{Behind-the-Scenes Tour, Field Museum of Natural History ACRL Anthropology and Soctology \\ Section}

Tuesday, June 27, 9:00 a.m-Noon

After ten years, the Antropology and Sociology Section of ACRL revisits Chicago's Field Museum of Natural History, one the country's leading anthropology and natural history museums. Tour includes the main library, anthropology library, Runnells Rare Book Room, and the anthropology laboratories and storage rooms. A reception with light refreshments follows.

Tickets are $\$ 5$, by advance registration not later than June 1; no refunds after June 1. Limited to the first 75 reservations received. For reservations, send checks (payable to) Gregory A. Finnegan, Tozzer Library, Harvard University, 21 Divinity Avenue, Cambridge, MA 012382089. 


ME

A tentative scbedule for $A L A$ 's Annual Conference in Chicago June 22-29, 1995

d. note: This list was current as C\&RL News went to press. Be sure to check the program book for the final schedule and location of meetings.

\section{ACRL Board of Directors}

First meeting: Saturday, June 24, 2:00-4:00 p.m.

Second meeting: Tuesday, June 27, 2:00-5:30 p.m.

New board members orientation: Friday, June 23, 9:30-11:00 a.m.

Planning Session: Friday, June 23, 2:00-5:30 p.m.

\section{ACRL General}

Membership Meeting and Awards Program: Monday, June 26, 4:00-4:30 p.m.

New Leader Orientation: Friday, June 23, 12:30-2:00 p.m.

New Member First Conference Reception: Monday, June 26, 1:00-2:00 p.m.

President's Program: Monday, June 26, 2:004:30 p.m. Topic: The Life of the Mind in the 21st Century"

Reception for Academic/Research Librarian of the Year:Monday, June 26, 4:30-6:00 p.m.

\section{ACRL Divisional Committees}

Academic Library Statistics: Sunday, June 25, 9:30-11:00 a.m.; Monday, June 26, 9:3011:00 a.m.

Academic Status: Sunday, June 25, 8:30-11:00 a.m.; Monday, June 26, 8:30-11:00 a.m.

AECT Joint Standards Committee for TwoYear Programs: Friday, June 23, 2:00-5:30 p.m.

Appointments and Nominations: Saturday, June 24, 2:00-4:00 p.m. (closed)

Atkinson Award: Saturday, June 24, 8:00-11:00 a.m. (closed)
Budget and Finance: Saturday, June 24, 8:30 a.m.-12:30 p.m.; Sunday, June 25, 9:30 a.m.-12:30 p.m.; Monday, June 26, 8:3011:30 a.m.; Tuesday, June 27, 9:30 a.m.12:30 p.m

Certification of Librarians Task Force: Saturday, June 24, 8:30-11:00 a.m.; Monday, June 26, 8:00-11:00 a.m.

CIO Initiative Advisory: Monday, June 26, 3:00-5:00 p.m.

Conference Program Planning-New York, 1996: Monday, June 26, 11:30 a.m.-12:30 p.m.

Conference Program Planning - San Francisco, 1997: Monday, June 26, 11:30 a.m.12:30 p.m.

Constitution and Bylaws: Saturday, June 24, 11:30 a.m.-12:30 p.m.; Monday, June 26, 9:3011:00 a.m.

Copyright: Sunday, June 25, 8:30-9:30 a.m

Diversity Mentor: Tuesday, June 27, 3:005:00 p.m.

EASI Advisory: Sunday, June 25, 3:00-5:00 p.m.

Electronic Reserves: Sunday, June 25, 8:0011:00 a.m.

Government Relations: Saturday, June 24, 8:009:00 a.m.; Monday, June 26, 8:00-11:00 a.m. Image Enhancement: Saturday, June 24, 9:3011:00 a.m.; Monday, June 26,9:30-11:00 a.m. Intellectual Freedom: Sunday, June 25, 2:004:00 p.m.

International Relations: Sunday, June 25, 8:30-11:00 a.m.

\section{Addreas the ACRL Board}

Share your concerns directly with ACR's Board of Directors. The first 21 minutes of the June 24, 1994, 2:00 p.m. meeting of the ACRL Board in Chicago will be given to an open-mike period. ACRL members may, on a first-come, first-served basis, address the Board (with a limit of three minutes per speaker) on any topic. The Board hopes this communication method will facilitate hearing the concerns and interests of ACRL members. 
Media Resources: Sunday, June 25, 9:3011:00 a.m. Program: Sunday, June 25, 2:00-4:00 p.m. Topic: The Great Media Convergence: "Evolving Relationships Between Campus Media and Information Systems and Services"

Membership: Sunday, June 25, 2:00-4:00 p.m.; Monday, June 26, 8:00-11:00 a.m.

National Conference Executive Committee, Nashville: Saturday, June 24, 8:30 a.m.12:30 p.m.; Monday, June 26, 7:00-9:00 a.m.

New Publications Advisory Board: Sunday, June 25, 11:30 a.m.-12:30 p.m.; Graphics Products Subcommittee: Saturday, June 24, 11:30 a.m.-12:30 p.m.

Planning (Interim): Friday, June 23, 8:0010:00 p.m.; Saturday, June $24,11: 30$ a.m.12:30 p.m.

President's Program, New York: Sunday, June 25, 9:30 a.m.-12:30 p.m.; Monday, June 26, 8:00-11:00 a.m.

Professional Education: Sunday, June 25 , 8:30 a.m.-11:00 a.m.

Professional Liaison: Sunday, June 25, 4:305:30 p.m.

Publications: Saturday, June 24, 8:30-11:00 a.m.; Monday, June 26, 8:30-11:30 a.m.

Racial and Ethnic Diversity: Saturday, June 24, 9:30-11:00 a.m.; Sunday, June 25, 9:3011:00 a.m., 2:00-4:00 p.m.

Research: Saturday, June 24, 9:30-11:00 a.m.; Monday, June 26, 9:30 a.m.-11:00 a.m.

Samuel Lazerow Fellowship in Acquisitii ons in Technical Services: Saturday, June 24, 11:30 a.m.-12:30 p.m. (closed)

Section Newsletter Editors: Monday, June 26, 8:00-9:00 a.m.

Stanciards and Accreditation: Sunday, June 25, 2:00-4:00 p.m.

Standards Study Task Force: Saturday, June 24, 8:00-11:00 a.m.

\section{ACRL Chapters Council}

Sunday, June 25, 8:30 a.m.-12:30 p.m.

\section{ACRL Editorial Boards}

Cboice: Sunday, June 25, 9:30 a.m.-12:30 p.m. College \& Research Libraries: Saturday, June 24, 2:00-4:00 p.m.

College \& Research Libraries News: Sunday, June 25, 9:30 a.m.-12:30 p.m.

Publications in Librarianship: Sunday, June 25, 8:00-9:00 a.m.
Rare Books \& Manuscripts Librarianship: Saturday, June 24, 2:00-4:00 p.m.

\section{ACRL Sections}

Activity Sections Council: Saturday, June 24, 8:30-10:00 a.m.

\section{Afro-American Studies Librarians Section}

Executive: Saturday, June 24, 2:00-4:00 p.m.

Communications \& Publications, Saturday, June 24, 8:00-9:00 a.m.

Constitution and Bylaws: Saturday, June 24, 8:00-9:00 a.m.

General Membership Meeting, Monday, June 26, 9:30-11:00 a.m.

Indexing Project: Saturday, June 24, 8:30-11:00 a.m.

Membership: Saturday, June 24, 8:00-9:00 a.m. Nominating: Saturday, June 24, 8:00-9:00 a.m.

Policy and Research: Saturday, June 24, 8:3011:00 a.m.

Program Planning, New York: Saturday, June 24, 9:30-11:00 a.m.

\section{Asian, African, and Middle Eastern Section}

Program: Monday, June 26, 9:30 a.m.-12:30 p.m. Topic: "Africa at the Field Museum: Perspectives on the New Permanent Africa Exhibit"

Executive: Sunday, June 25, 2:00-4:30 p.m.

\section{Anthropology and Sociology Section}

Program: Sunday, June 25, 9:30 a.m.-12:30 p.m. Topic: "Publishing the Social Text: Issues in Sociology and Anthropology Publication and Reviewing?"

Executive: Monday, June 26, 8:30-11:00 a.m.

Anthropology Librarians Discussion Group: Monday, June 26, 4:30-5:30 p.m.

Bibliography: Saturday, June 24, 8:30-11:00 a.m.

Conference Program Planning-Chicago, 1995: Sunday, June 25, 8:00-9:00 a.m.

Conference Program Planning-New York, 1996: Saturday, June 24, 8:00-9:00 a.m.

Electronic Resources for Sociologists (ad hoc), Saturday, June 24, 8:00-9:00 a.m.

Liaison: Sunday, June 25, 2:00-4:00 p.m.

Nominating: Saturday, June 24, 11:30 a.m.12:30 p.m. (closed) 


\section{A C C R R L}

Publications: Sunday, June 25, 2:00-4:00 p.m. Review and Planning: Sunday, June 25, 4:305:30 p.m.

Sociology Librarians Discussion Group: Saturday, June $24,11: 30$ a.m.-12:30 p.m.

Tour: Tuesday, June 27, 9:00 a.m.-noon.

\section{Arts Section}

Program: Saturday, June 24, 2:00-4:00 p.m. Topic: "Diverse Images of Chicago Dance: From Cooperative Preservation to Cutting Edge"

Executive and Membership Meeting: Sunday, June 25, 9:30 a.m.-12:30 p.m

All Committees: Saturday, June 24, 9:30 a.m.12:30 p.m.

Dance Librarians Discussion Group: Monday, June 26, 8:30-11:00 a.m.
Dance Video Interlibrary Loan Subcommittee: Saturday, June 24, 8:00-9:00 a.m.

Film/Television Discussion Group: Monday, June 26, 2:00-4:00 p.m.

Technology in the Arts: Monday, June 26, 9:30 a.m.-12:30 p.m. Topic: "Art Information Update: Imaging and Standards Issues for Encoding"

\section{Bibliographic Instruction Section}

Program: Sunday, June 25, 2:00-5:30 p.m. Topic: "Measuring Up: Improving Instruction Through Evaluation"

Executive: Friday, June 23, 9:30 a.m.-12:30 p.m.; Tuesday, June 27, 8:30-11:00 a.m.

Advisory Council: Saturday, June 24, 9:3011:00 a.m.; Monday, June 26, 9:30-11:00 a.m. Awards: Saturday, June 24, 2:00-4:00 p.m. (closed)

\section{ACRL discussion groups}

Ed. note: All section discussion groups are listed with their sections.

Alliance for New Directions in Teaching and Learning: Monday, June 26, 8:00-9:00 a.m.

Australian Studies: Sunday, June 25, 11:30 a.m.-12:30 p.m. Topic:" "Librarian Exchanges"

Canadian Studies: Sunday, June 25, 11:30 a.m.-12:30 p.m. Toptc: "Mounting Canadian Studies Information on the Internet"

Electronic Library: Saturday, June 24, 11:30 a.m.-12:30 p.m.

Electronic Text Centers: Saturday, June 24, 2:00-4:00 p.m. Topic: "Putting Texts on the Web: Some Perspectives"

Exhibits and Displays in Libraries: Saturday, June 24, 9:30 a.m.-12:30 p.m.

Fee-based Information Service Centers in Academic Libraries (F.I.S.C.A.L.): Saturday, June 24, 2:00-4:00 p.m. Topics: Conference planning and CCC's new Internet reporting service; Sunday, June 25 , 9:00-11:00 a.m. (joint with ILERT) Toptc: "Marketing your Skills"

Heads of Public/Readers Services: Sunday, June 25, 4:30-6:00 p.m. Topic: "Putting Users First: A Team Approach to Reengineering Library Services"

Home Economics/Human Ecology: Sunđay, June 25, 4:30-5:30 p.m. Topic: "Resources in Home Economics on the Internet and the World Wide Web"
Journal Costs in Academic Libraries: Saturday, June 24, 2:00-4:00 p.m.

Library Development Officers: Sunday, June 25, 9:30-11:00 a.m. Topic: "An Update Since Albuquerque"

Librarians of Library Science Collections: Saturday, June 24, 9:30-11:00 a.m.

MLA International Bibliography in Academic Libraries: Saturday, June 24, 9:30 a.m. $-12: 30$ p.m.

Personnel Administrators and Staff Development Officers: Saturday, June 24, 9:30 -11:00 a.m.; Sunday, June 25, 9:30 a.m.-12:30 p.m. Toprc: "Applying ILC: Managing Team Learning for Change"; Monday, June $26,9: 30-11: 00 \mathrm{a} . \mathrm{m}$.

Philosophical, Religious, and Theological Studies: Monday, June 26, 9:30-11:00 a.m. American Theological Library Association representatives will discuss recent products.

Popular Culture and Libraries: Sunday, June 25, 4:30-5:30 p.m. Topic: "Popular Culture Resources on the Internet"

Public Relations in Academic Libraries: Sunday, June $25,4: 30-5: 30$ p.m.

Research: Monday, June 26, 2:00-4:00 p.m. Undergraduate Librarians: Monday, June 26, 8:30-11:00 a.m. 
Communications: Saturday, June 24, 2:00-4:00 p.m.

Conference Program Planning-Chicago, 1995: Saturday, June 24, 11:30 a.m.-12:30 p.m.

Conference Program Planning-New York, 1996: Sunday, June 25, 9:30 a.m.-12:30 p.m. Continuing Education: Sunday, June 25, 9:3011:00 a.m.

Education for Bibliographic Instruction: Saturday, June 24, 2:00-4:00 p.m.

Emerging Technologies in Instruction Discussion Forum: Saturday, June 24, 2:00-4:00 p.m.

Evaluating the Bibliograpbic Instruction Handbook: Sunday, June 25, 9:30-11:00 a.m.

Guidelines for BI Open Hearing: Sunday, June 25, 8:00-9:00 a.m.

Guidelines for BI Task Force: Sunday, June 25, 9:30-11:00 a.m.

Instruction for Diverse Populations: Sunday, June 25, 9:30-11:00 a.m.

Management of Bibliographic Instruction Services: Saturday, June 24, 2:00-4:00 p.m.

Membership: Sunday, June 25, 9:30 a.m.-12:30 p.m.

New Chair Orientation: Saturday, June 24, 11:30 a.m.-12:30 p.m.

Nominating 1996: Sunday, June 25, 9:30 a.m.12:30 p.m. (closed)

Planning: Sunday, June 25, 9:30 a.m.-12:30 p.m.

Preconference Policy Handbook Task Force: Saturday, June 24, 11:30 a.m.-12:30 p.m.

Policy: Sunday, June 25, 9:30-11:00 a.m.

Teaching Methods: Sunday, June 25, 9:30 a.m. $-12: 30$ p.m.

Video: Saturday, June 24, 2:00-4:00 p.m.

\section{Community and Junior College Libraries Section}

Program: Friday, June 23, 7:00-10:00 p.m. Topic: "Lyman Shepard as Frank Lloyd Wright: A Dramatic Presentation" (Nick and Tony's Restaurant)

Program: Saturday, June 24, 9:30 a.m.-12:30 p.m. Topic: "Stepping Towards the Virtual Library: Planning, Practice, and Dreams"

Tour: The Learning Resources Center, College of DuPage, Monday, June 26, 7:30-11:30 a.m.

Executive: Sunday, June 25, 11:30 a.m.-12:30 p.m.; Tuesday, June 27, 8:30-11:00 a.m.

ACRL/CJCLS/NCLR Joint Discussion Group: Sunday, June 25, 2:00-4:00 p.m.
All Committees: Sunday, June 25, 8:30 a.m.-11:00 a.m.

Awards: Saturday, June 24, 2:00-4:00 p.m. (closed)

Conference Program Planning-New York, 1996 Saturday, June 24, 2:00-4:00 p.m.

EBSCO Awards Presentation: Saturday, June 24, 8:00-9:30 a.m.

Library/Media Technician Training: Sunday, June 25, 8:00-10:00 p.m. Open Hearings on Current Criteria for Programs to Prepare Library/Media Technician Assistants

Nominating, 1996: Saturday, June 24, 2:00-4:00 p.m. (closed)

\section{College Libraries Section}

Program: Sunday, June 25, 9:30 a.m.-12:30 p.m. Topic. "Run Ragged by Riches! Technology and Changing Communications for the Library"

Reception: Sunday, June 25, 4:00-6:00 p.m

Executive: Saturday, June 24, 9:30 a.m.-12:30 p.m.; Tuesday, June 27, 9:30 a.m.-12:30 p.m.

CLIP Notes: Saturday, June 24, 8:00-11:00 a.m. College Library Leadership: Monday, June 26, 8:00-11:00 a.m. Topic: "So You Want to be a College Library Director?"

Conference Program Planning-New York, 1996: Saturday, June 24, 2:00-4:00 p.m.

Conference Program Planning-Chicago, 1995:

Saturday, June 24, 2:00-4:00 p.m.

Continuing Education: Monday, June 26, 8:0011:00 a.m

Discussion Forums: Sunday, June 25, 8:00-9:00 a.m.

Library Directors Discussion Group: Sunday, June 25, 2:00-4:00 p.m.

Medium-Sized Academic Libraries, Saturday, June 24, 8:00-9:00 a.m.

Medium-Sized Academic Libraries Discussion Group, Monday, June 26, 8:30-11:00 a.m.

Newsletter: Saturday, June 24, 2:00-4:00 p.m.

Nominating, Saturday, June 24, 2:00-4:00 p.m.

Pittsburgh Preconference: Saturday, June 24, 2:00-4:00 p.m.

Planning: Saturday, June 24, 2:00-4:00 p.m.; Monday, June 26, 9:30 a.m.-12:30 p.m.

Research for College Librarianship: Monday, June 26, 8:30-11:00 a.m.

Standards: Monday, June 26, 9:30-11:00 a.m.

Women's Colleges Discussion Group: Monday, June 26, 8:00-9:00 a.m. 


\section{Education and Behavioral Sciences Section}

Program: Monday, June 26, 9:30 a.m.-12:30 p.m. Topic: "Distance Education in the 21st Century: Removing the Campus Walls"

Executive: Friday, June 23, 8:00-10:00 p.m.; Tuesday, June 27, 8:30 a.m.-12:30 p.m.

Bibliographic Instruction for Educators: Sunday, June 25, 9:30 a.m.-12:30 p.m.

Business Meeting: Monday, June 26, 8:00-9:00 a.m.

Conference Program Planning-New York, 1996: Saturday, June 24, 2:00-4:00 p.m.

Conference Program Planning-Chicago, 1995: Saturday, June 24, 9:30-11:00 a.m.

Current Topics Discussion Group: Saturday, June 24, 2:00-4:00 p.m.

Curriculum Materials: Sunday, June 25, 2:005:30 p.m.

Curriculum Materials Directory Revision: Sunday, June 25, 8:00-10:00 p.m.

Governmental Policy: Sunday, June 25, 9:3011:00 a.m.

Nominating: Saturday, June 24, 9:30-11:00 a.m. (closed)

Orientation Manual (ad hoc): Sunday, June 25, 2:00-4:00 p.m.

Problems of Access and Control of Education Materials: Sunday, June 25, 2:00-5:30 p.m.

Psychology/Psychiatry: Sunday, June 25, 8:0011:00 a.m.

Publications: Saturday, June 24, 8:00-9:00 a.m. Reference Sources and Services: Saturday, June 24, 9:30 a.m.-12:30 p.m.

Social Work/Social Welfare: Sunday, June 25 , 2:00-4:00 p.m.

\section{English and American Literature Section}

Program: Sunday, June 25, 9:30 a.m.-12:30 p.m.; Topic: "The Humanist and the Librarian: Creating a Collaborative Partnership"

Executive: Monday, June 26, 2:00-4:00 p.m. Bylaws: Tuesday, June 27, 8:30-11:00 a.m.

Program Planning-New York, 1996: Monday, June 26, 4:30-5:30 p.m.

Publications: Monday, June 26, 4:30-5:30 p.m.

\section{Extended Campus Library Services Section}

Program: Saturday, June 24, 2:00-4:00 p.m. Topic: "Can This Marriage Be Saved? Academic and Public Librarians Working To- gether to Support Extended-Campus Students"

Executive: Saturday, June 24, 8:00-10:00 p.m.; Sunday, June 25, 11:30 a.m.-12:30 p.m.

Communications: Sunday, June 25, 8:30-11:00 a.m.

Conference Program Planning-New York, 1996: Sunday, June 25, 8:30-11:00 a.m.

Conference Program Planning-Chicago, 1995:

Sunday, June 25, 8:30-11:00 a.m.

Discussion Group: Monday, June 26, 8:00-11:00 a.m.

Membership: Sunday, June 25, 8:30-11:00 a.m.

Planning: Sunday, June 25, 8:30-11:00 a.m.

Research: Sunday, June 25, 8:30-11:00 a.m.

Statistics: Sunday, June 25, 8:30-11:00 a.m.

\section{Law and Political Sciences Section}

Preconference: Friday, June 23, 8:00 a.m.-5:30 p.m. Topic: "Taking the Mystery Out of Legal Research for Non-law Librarians"

Program: Saturday, June 24, 2:00-4:00 p.m. Topic: The United Nations at 50: Information Services, Policies, and Documentation"

20th Anniversary Breakfast: Saturday, June 24, 8:30-11:00 a.m.

Executive: Saturday, June 24, 9:30 a.m.-12:30 p.m.

Conference Program Planning-New York, 1996: Saturday, June 24, 11:30 a.m.-12:30 p.m.

General Membership Meeting: Tuesday, June 27, 9:30 a.m.-12:30 p.m.

Library Instruction: Sunday, June 25, 2:00-5:30 p.m.

Marta Lange/CQ Award: Sunday, June 25, 11:30 a.m. $-12: 30$ p.m.

Membership: Monday, June 26, 4:30-5:30 p.m.

Publications: Monday, June 26, 8:30-11:00 a.m.

Review and Planning: Sunday, June 25, 9:30-11:00 a.m.

Services to Academic Community: Saturday, June 24, 11:30 a.m.-12:30 p.m.

Vendor/Publisher Review: Sunday, June 25, 9:30-11:00 a.m.

\section{Rare Books and Manuscripts Section}

Preconference: Tuesday-Friday, June 20-23. Topic: "Collecting Cultures: The Politics and Practice of Building Special Collections"

Program: Sunday, June 25, 2:00-4:00 p.m.; 
Topic: "The Age of Anxiety: Balancing Scholarly Needs for Primary Research Materials and Electronic Information"

Executive: Saturday, June 24, 8:00-10:00 p.m.; Monday, June 26, 8:00-11:00 a.m.

Bibliographic Standards: Saturday, June 24, 8:30-11:00 a.m.; Sunday, June 25, 8:30-11:00 a.m.

Budget and Development: Saturday, June 24, 8:00-11:00 a.m.

Conference Development: Sunday, June 25, 8:30-11:00 a.m.

Conference Program Planning-New York, 1996: Saturday, June 24, 11:30 a.m.-12:30 p.m.

Curators and Conservators Discussion Group: Sunday, June 25, 8:30-11:00 a.m.

Education and Professional Development: Saturday, June 24, 2:00-4:00 p.m.

Electronic Information Technologies (ad hoc): Sunday, June 25, 8:30-11:00 a.m.

Exhibition Catalogue Awards: Saturday, June 24, 9:30 a.m.-12:30 p.m. (closed); Sunday, June 25, 8:30 a.m.-12:30 p.m.

Manuscripts and Other Formats Discussion Group: Saturday, June 24, 9:30-11:00 a.m.

MARC for Special Collections (MASC) Discussion Group: Sunday, June 25, 11:30 a.m.12:30 p.m.

Membership (Ad hoc): Saturday, June 24, 9:30-11:00 a.m.

Nominating: Sunday, June 25, 11:30 a.m12:30 p.m. (closed)

Preconference Program Planning, New York1996: Sunday, June 25, 2:00-4:00 p.m.

Preconference Program Planning-San Francisco, 1997: Sunday, June 25, 11:30 a.m.-12:30 p.m.

Publications: Saturday, June 24, 9:30-11:00 a.m.

RRML Award: Sunday, June 25,8:00-10:00 p.m.

RBMS Award: Sunday, June 25, 8:00-10:00 p.m.

Security: Saturday, June 24, 9:30-11:00 a.m. Seminars: Sunday, June 25, 8:00-10:00 p.m.

\section{Slavic and East European Section}

Program: Sunday, June 25, 2:00-4:00 p.m.; Topic: "Librarians Riding the Bear: Keeping Pace with Russian Publishing"

Executive: Monday, June 26, 4:30-5:30 p.m.

Automated Bibliographic Control: Monday, June 26, 9:30-11:00 a.m.
Conference Program Planning-Chicago, 1995: Sunday, June 25, 8:00-9:00 a.m.

Conference Program Planning-New York, 1996: Monday, June 26, 8:00-9:00 a.m.

Continuing Education: Sunday, June 25, 9:3011:00 a.m.

Membership: Sunday, June 25, 4:30-5:30 p.m. Newsletter Editorial Board: Sunday, June 25,

11:30 a.m.-12:30 p.m.

Nominating: Tuesday, June 27, 8:00-9:00 a.m. (closed)

Preservation: Monday, June 26, 2:00-4:00 p.m.

\section{Science and Technology Section}

Program: Monday, June 26, 8:00-11:00 a.m.

Topic: "Preserving the Record of Science and Technology: A Call to Action"

Reception: Sunday, June 25, 6:00-8:00 p.m., Adler Planetarium

Council: Friday, June 23, 8:00-10:00 p.m.; Monday, June 26, 8:00-10:00 p.m.

College Science Librarians Discussion Group: Saturday, June 24, 9:30-11:00 a.m. Topic. Electronic Science Journals in the Undergraduate College Library"

Comparison of Science and Technology Libraries: Saturday, June 24, 8:30 a.m.-12:30 p.m. Conference Program Planning-Chicago, 1995: Saturday, June 24, 9:30 a.m.-12:30 p.m.

Conference Program Planning-New York, 1996: Sunday, June 25, 8:30 a.m.-12:30 p.m. Continuing Education: Saturday, June 24, 11:30 a.m.-12:30 p.m.

Forum on Emerging Issues and Research: Tuesday, June 27, 8:30-11:00 a.m. (closed)

\section{ACRL Preconforences}

Ed. note: Advance registration is required; a full description of the following preconferences may be found in the April 1995 CERL News or contact the ACRL office at (800) 545-2433 ext. 2521 for details.

Taking the Mystery Out of Legal Research for Non-Law Lbrarians-Sponsored by the Law and Political Science Seetion, PLA, RASD, and AALL, June 23, 1995. Collecting Cultures: The Politics and Practice of Bullding Special Collections-Sponsored by the Rare Books and Manuscripts Section, June 20-23, 1995. 


\section{$\begin{array}{llllllllllll}A & C & R & L & M & E & E & T & I & N & G & S\end{array}$}

General Discussion Group/Research ForumVI: Sunday, June 25, 2:00-5:00 p.m.

Heads of Science Libraries Discussion Group Sunday, June 25, 8:00-10:00 p.m.

Legislation: Saturday, June 24, 8:00-10:00 p.m.; Sunday, June $25,11: 30$ a.m.-12:30 p.m.

Membership: Sunday, June 25, 11:30 a.m.-12:30 p.m.

Nominating: Sunday, June 25, 11:30 a.m.-12:30 p.m. (closed)

Oberly Award: Saturday, June 24, 11:30 a.m.12:30 p.m.

Planning: Sunday, June 25, 11:30 a.m.-12:30 p.m.

Publications: Saturday, June 24, 11:30 a.m-12:30 p.m.

Publisher/Vendor Relations: Saturday, June 24, 9:30-11:00 a.m.

Science Databases Discussion Group: Sunday, June 25, 9:30-11:00 a.m.

Subject and Bibliographic Access: Sunday, June $25,11: 30$ a.m.-12:30 p.m.

\section{University Libraries Section}

Program: Saturday, June 24, 2:00-4:00 p.m. Topic: "But What About Me? The Human Face of Organizational Change"

Executive: Saturday, June 24, 9:30-11:00 a.m.; Monday, June 26, 9:30-11:00 a.m.;

Communications: Saturday, June 24, 11:30 a.m.12:30 p.m.; Tuesday, June 27, 9:30-11:00 a.m.

Conference Program Planning-New York, 1996: Sunday, June 25, 2:00-4:00 p.m.

Current Topics Discussion Group: Sunday, June 25, 11:30 a.m.-12:30 p.m.

Hearing on Draft Guidelines for University Undergraduate Libraries: Monday, June 26, 4:30-5:30 p.m.

Librarians in Higher Education Discussion Group: Sunday, June 25, 9:30-11:00 a.m.

Nominating: Saturday, June 24, 8:00-9:00 a.m. (closed)

Organization and Bylaws: Sunday, June 25, 2:00-4:00 p.m.

Policy and Planning: Sunday, June 25, 9:3011:00 a.m.

Public Services Directors of Large Research Libraries Discussion Group: Sunday, June 25, 2:00-4:00 p.m.

\section{Western European Specialists Section}

Program: Monday, June 26, 9:30-11:00 a.m. Topic: "European Connections: Electronic Resources for Western Europe"

Executive: Tuesday, June 27, 2:00-4:00 p.m.

Classical, Medieval, and Renaissance Discussion Group: Saturday, June 24, 2:00-4:00 p.m.

College and Medium-Sized Libraries Discussion Group: Monday, June 26, 4:30-5:30 p.m.

Conference Program Planning-New York, 1996: Saturday, June 24, 2:00-4:00 p.m.

General Membership Meeting and Discussion Group: Monday, June 26, 8:00-9:00 a.m.

German Social Sciences Working Group: Sunday, June 25, 8:00-9:00 a.m.

Germanists Discussion Group: Sunday, June 25, 9:30-11:00 a.m.

Internet Publications Committee: Tuesday, June 27, 8:00-9:00 a.m.

Preconference Program Planning,-San Francisco, 1997: Monday, June 26, 4:30-5:30 p.m.

Publications: Tuesday, June 27, 9:30-11:00 a.m.

Research and Planning: Sunday, June 25, 2:004:00 p.m.

Romance Languages Discussion Group: Monday, June 26, 2:00-4:00 p.m.

Scandinavian Discussion Group: Sunday, June $25,8: 00-9: 00$ a.m

\section{Women's Studies Section}

Program: Monday, June 26, 9:00-11:00 a.m. Topic: "New Feminist Research in Library and Information Science: Implications for Librarianship"

Executive: Saturday, June 24, 2:00-4:00 p.m.; Monday, June 26, 2:00-4:00 p.m.

Collection Development and Bibliography: Sunday, June 25, 9:30 a.m.-12:30 p.m.

Communications: Sunday, June 25, 9:30 a.m.-12:30 p.m.

Conference Program Planning-New York, 1996: Sunday, June 25, 9:30 a.m.-12:30 p.m.

General Membership Meeting: Sunday, June 25, 4:30-5:30 p.m.

Publications: Sunday, June 25, 9:30 a.m.-12:30 p.m.

Social Issues/Education: Sunday, June 25, 9:30 a.m. $-12: 30$ p.m.

Technical Services: Sunday, June 25, 9:30 a.m. $-12: 30$ p.m. 
sated? Is staff development encouraged and supported?

e. What is the ratio of public services staff to the number of primary clientele? Is this an acceptable ratio?

f. Are additional services needed?

g. Are new services, which are needed by users, anticipated and implemented?

2) Collections and Access. There is no absolute standard for the size of a collection in undergraduate libraries. The essential criterion is that the collections (or access to information outside of the collection) adequately support the needs of the primary clientele. The collection policy should adequately describe the collection goals and be evaluated with the following factors considered:

a. Does the collection profile adequately support the undergraduate curriculum?

b. Does the size and depth of the collection adequately support the size and need of the undergraduate population?

c. Are materials appropriately available and accessible for reserve users?

d. Are collections effectively included in the catalog? Are comparable standards of bibliographic access followed for undergraduate library collections as in the overall library system?

e. Are collections housed and arranged efficiently and effectively for use by the primary clientele?

f. Are collections available and accessible to all users? Do circulation policies and practices permit effective access for users?

g. Are access policies posted to insure that all users are aware of services and restrictions?

h. Do appropriate withdrawal policies and practices exist which adequately address the need for collection maintenance?

i. Are interlibrary loan and other document delivery services provided for undergraduates to give them access to materials not owned by the institution?

j. Do undergraduates have adequate access to electronic networks for accessing information?

3) Environment. Undergraduate libraries require appropriate facilities to provide the services and collections necessary to accomplish their missions.

a. Is the facility safe and environmentally controlled?

b. Are materials adequately safeguarded against loss, mutilation, theft, or other damage?

c. Is adequate equipment and technical support available? d. Is appropriate seating and user space available?

e. Is space appropriately allocated for use including group and instructional use, study, research, use of information technologies?

f. Are facilities accessible to all users?

g. Does space allow for cooperative programs with other library and campus units?

4) Adequacy of the budget.

a. Is the budget comparable to other undergraduate libraries at comparable institutions?

b. Does the budget support appropriate levels of staffing?

c. Does the budget provide adequate support for baseline services?

d. Does the budget adequately support the collection policy to provide materials or access to materials in support of undergraduate students' library needs?

e. Is the budget flexible enough to support necessary new programs and innovations, including integration of new technologies and instructional programs?

f. Are the library and information needs of undergraduate students represented adequately in the budget process?

g. Does the undergraduate library's personnel have discretion and control of its budget?

h. Do staffing and budget allocations allow for long-term planning initiatives?

\section{Reassessment}

Evaluation and assessment is a continuous process in undergraduate libraries because of the changing nature of their primary clientele and the curriculum. Communication with the overall library administration and with campus groups is a critical factor. In addition to these ongoing evaluation processes, the performance of undergraduate libraries should be periodically subjected to formal reviews. Reviews will vary depending on the mechanisms adopted by the parent institution. Findings from evaluations should be written and widely discussed in order to solicit involvement by students, faculty, and other library units. The outcome of reviews should be a reassessment of the goals and objectives of undergraduate libraries. Realistic goals and expectations of future services to be offered by undergraduate libraries should be developed. By this process, the university, the overall library system, and the undergraduate library should maintain a balance between resources and mission. 


\section{The Virtual Library Is Here.}

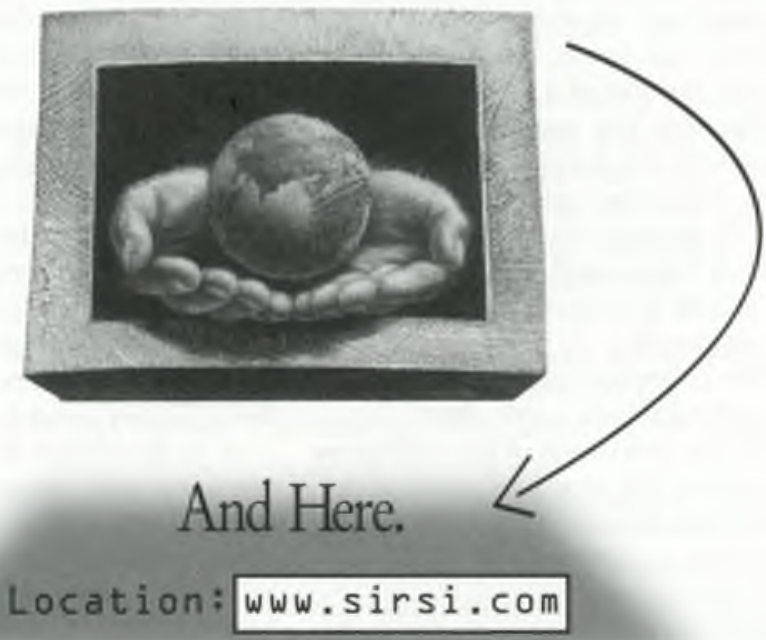

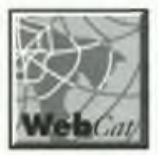

WebCat $^{\text {IM }}$ is here. And it's the most exciting library automation breakthrough of the decade. To see it for yourself, take a test drive on our Home Page at: www.sirsi.com.

When you see WebCat, you'll see that library walls are coming down. You'll see that in their place stand more than 5 million users of the World Wide Web. WebCat places you at the center of your patrons' information world. It places you on the leading edge of the

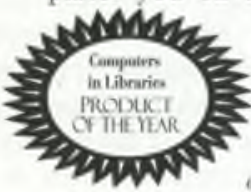

information revolution.
All you need is a $\mathbf{Z 3 9 . 5 0}$ server. All your patrons need is a Web browser like Mosaic ${ }^{\mathrm{TM}}$ or NETSCAPE. ${ }^{\mathrm{TM}}$ WebCat does the rest, tuming your library and all public access services into a full-fledged Web catalog.

There is no proprietary client software to distribute. There is no training required for researchers to access your library collection through your Web Home Page.

For the complete WebCat story, call Sirsi at 205-922-9820. For the complete WebCat experience, well, you have the address.

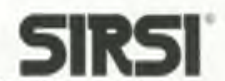

